\title{
Virulence tests of Neofusicoccum parvum, Lasiodiplodia theobromae, and Phytophthora palmivora on Theobroma cacao
}

\author{
A. S. Puig • L. M. Keith • T. K. Matsumoto • \\ O. A. Gutierrez • J. P. Marelli
}

Accepted: 19 January 2021 /Published online: 10February 2021

(C) This is a U.S. government work and not under copyright protection in the U.S.; foreign copyright protection may apply 2021

\begin{abstract}
Neofusicoccum parvum is a recently reported pathogen affecting Theobroma cacao L., and has been isolated from symptomatic pods on Oahu and Hawaii Islands. Determining infection routes and virulence are essential for assessing the impact of $N$. parvum on cacao production and developing effective disease management strategies. Infection routes were determined by inoculating unwounded stems and pods with six isolates of $N$. parvum alongside Lasiodiplodia theobromae and Phytophthora palmivora. Fifty percent of unwounded stems inoculated with $P$. palmivora developed lesions, but only a single lesion developed following inoculation with $N$. parvum (isolate H44). L. theobromae and the remaining $N$. parvum isolates did not induce lesion development on unwounded stems. In contrast, all $N$. parvum and L. theobromae isolates produced lesions on $40-100 \%$ of unwounded pods of GNV 164 and GNV 360. Low incidences of infection were observed in unwounded pods of ICS $95(0-66.7 \%)$, SHRS 21 (0$75 \%$ ), and SHRS $33(0-20 \%)$. On wounded pods, all pathogen species produced similar size lesions, ranging
\end{abstract}

A. S. Puig $(\bowtie) \cdot$ O. A. Gutierrez

Subtropical Horticultural Research Station, USDA-ARS, Miami, FL, USA

e-mail: alina.puig@usda.gov

L. M. Keith · T. K. Matsumoto

Daniel K. Inouye U.S. Pacific Basin Agricultural Research Center, USDA-ARS, Hilo, HI, USA

J. P. Marelli

Mars Wrigley Plant Sciences Laboratory, Davis, CA, USA from 1.90 to $7.60 \mathrm{~cm}$ four days after inoculation. Results from this study show that all three species can produce high rates of pod infection on some clones in the absence of wounds, but stem infection is less likely. In addition, this is the first report of $L$. theobromae infecting cacao pods and $P$. palmivora infecting stems in the absence of wounds.

Keywords Neofusicoccum parvum $\cdot$ Lasiodiplodia theobromae. Theobroma cacao Phytophthora palmivora Pod rot . Black pod $\cdot$ Canker

\section{Introduction}

Commercial production of cacao in Hawaii has doubled in the past 10 years, and farms are now present on most of the islands (Bittenbender 2005). Since 2008, an estimated 19,000 cacao trees have been planted in the state, bringing the commercial production area to 138 ha, making cacao the crop with the greatest expansion in production for the state (USDA 2016). Although many of the principal cacao diseases (cacao swollen shoot disease, frosty pod rot, witches' broom, and vascular streak dieback) are absent, little information exists regarding the presence of other cacao diseases that could affect the crop in the area. Diseases were rated the most important issue facing the Hawaii chocolate industry (Bittenbender 2016) but few studies have been conducted to date.

Neofusicoccum parvum was recently identified as a causal agent of pod rot on T. cacao (Puig et al. 2019), 
and additional information is needed regarding its biology and relative virulence. Although $N$. parvum is reported to cause fruit rot in strawberry (Oliveira et al. 2019) as well as in walnut (Chen et al. 2019), it is more commonly known as a stem pathogen, causing grapevine decline (Úrbez-Torres and Gubler 2009) and canker/dieback in Eucalyptus, 'Ohi'a, and apple (Iturritxa et al. 2011; Hughes et al. 2018; Rusin et al. 2019). In avocado and mango, it causes disease on both the fruit and woody tissue (Zea-Bonilla et al. 2007; HuiFang et al. 2012; Molina-Gayosso et al. 2012; Ismail et al. 2013). High density planting is becoming more common on T. cacao plantations, which requires more frequent pruning to manage growth. Botryosphaeria species. Such as N. parvum, N. batangarum, and $L$. theobromae are considered wound-invading pathogens, and greater pruning increases the availability of infection sites. Pruning wounds have been established as natural entry points for $N$. parvum in grape (Luque et al. 2014) but determining the ability of this organism to infect intact plant tissue is important for designing management strategies. Accurate field diagnosis is an additional obstacle, as symptoms caused by $N$. parvum closely resemble those caused by Lasiodiplodia theobromae and Phytophthora palmivora, which are present in nearly all cacao producing areas (Fig. 1).

Establishing the infection cycle of emerging pathogens is an important step toward developing effective disease management strategies. The objectives of this study were to (i) determine growth rate and temperature response of isolates, (iii) compare virulence of N. parvum, Lasiodiplodia theobromae and Phytophthora palmivora, and (iv) determine the ability of these organisms to infect unwounded pods and stems.

\section{Materials and methods}

Pathogen isolation and identification

Six isolates of N. parvum (H20, H23, H24, H40, H44, H45) were obtained from symptomatic pods of $T$. cacao on Oahu and Hawaii Islands. Symptomatic pods were sampled and taken to the USDA-ARS Daniel K. Inouye U.S. Pacific Basin Agricultural Research Center in Hilo and Hawaii Agriculture Research Center in Kunia, for isolation, as described in Puig et al. (2019). To minimize recovery of saprophytes and secondary organisms, samples of symptomatic pod tissue were baited into healthy, 3-4-month-old cacao pods (Chee and Foong 1968). Symptomatic pods were processed by excising pieces (approximately $3 \times 15 \times 3 \mathrm{~mm} 3$ ) from lesion margins comprising both healthy and necrotic tissue, surfacedisinfesting by immersing in $70 \%$ ethanol for $20 \mathrm{~s}$, and air drying on autoclaved filter paper. These pieces were cut into $1 \times 5 \times 3 \mathrm{~mm} 3$ strips, inserted into openings made in the bait pods, wrapped in parafilm, and incubated at room temperature $\left(25 \pm 3{ }^{\circ} \mathrm{C}\right)$ for three days. Pathogens were isolated from the margins of lesions developing around the bait sites as described above and plated on $1 / 2$ strength potato dextrose agar (PDA) (Sigma Chemical Co., St. Louis, Mo; 19.5 g PDA, $7.5 \mathrm{~g}$ agar, and $1 \mathrm{~L}$ distilled water), and incubating at 25 $\left( \pm 3{ }^{\circ} \mathrm{C}\right)$.

Emerging hyphae were subcultured onto to new plates of $1 / 2$ PDA, and after six days, pieces of colonized media were excised and shipped to the Plant Pathology Laboratory at the USDA-ARS Subtropical Horticulture Research Station (SHRS) in Miami, FL (Interstate movement permit \#P526P-16-03047). Isolates were purified by single hyphal tip transfer to new $1 / 2$ PDA plates and maintained in the dark at laboratory temperature $\left(28 \pm 3{ }^{\circ} \mathrm{C}\right)$. DNA was extracted from 10-day-old mycelium, using the Qiagen DNeasy Plant Mini Kit, following the manufacturer's protocol (Qiagen, Valencia, CA).

To identify isolates, the internal transcribed spacer (ITS) region (ITS 1, 5.8S rRNA gene and ITS 2), the translation elongation factor $1-\alpha$ gene (TEF $1-\alpha)$, and partial sequence of the $\beta$-tubulin gene $(\beta$-tub) were amplified and sequenced using primers ITS1F $\left(5^{\prime}\right.$ CTTGGTCATTTAGAGGAAGTAA $\left.3^{\prime}\right)$ and ITS4 (5' TCCT CCGCTTATTGATATGC $3^{\prime}$ ) (White et al. 1990), EF1-728F (5' CATCGAGAAGTTCG AGAAGG 3') and EF1-986R (5' TACTTGAA GGAACCCTTACC 3') (Carbone and Kohn 1999), BT2A (5' GGTAACCAAATCGGTG CTGCTTTC3') and BT2B (5'ACCCTCAGTGTAGTGACCCTTGGC 3') (Glass and Donaldson 1995), respectively. PCR was performed in $20 \mu \mathrm{L}$ volumes, consisting of $10 \mu \mathrm{L}$ $2 \times$ GoTaq green master mix (Promega), $0.4 \mu \mathrm{L}$ each of $5 \mu \mathrm{m}$ forward and reverse primer, $10 \mathrm{ng}$ genomic DNA and sterile milli $\mathrm{Q}$ water to $20 \mu \mathrm{L}$. Thermal cycling conditions were $95{ }^{\circ} \mathrm{C}$ for $10 \mathrm{~min}$; then 30 cycles of $95^{\circ} \mathrm{C}$ for $30 \mathrm{~s}, 57^{\circ} \mathrm{C}$ for $30 \mathrm{~s}$ and $72{ }^{\circ} \mathrm{C}$ for $45 \mathrm{~s}$; and a final step of $72{ }^{\circ} \mathrm{C}$ for $5 \mathrm{~min}$. PCR products were electrophoresed through $1 \%(w / v)$ agarose gels containing $6 \mu \mathrm{l}$ of gelRed and visualized using a Typhoon 9410 


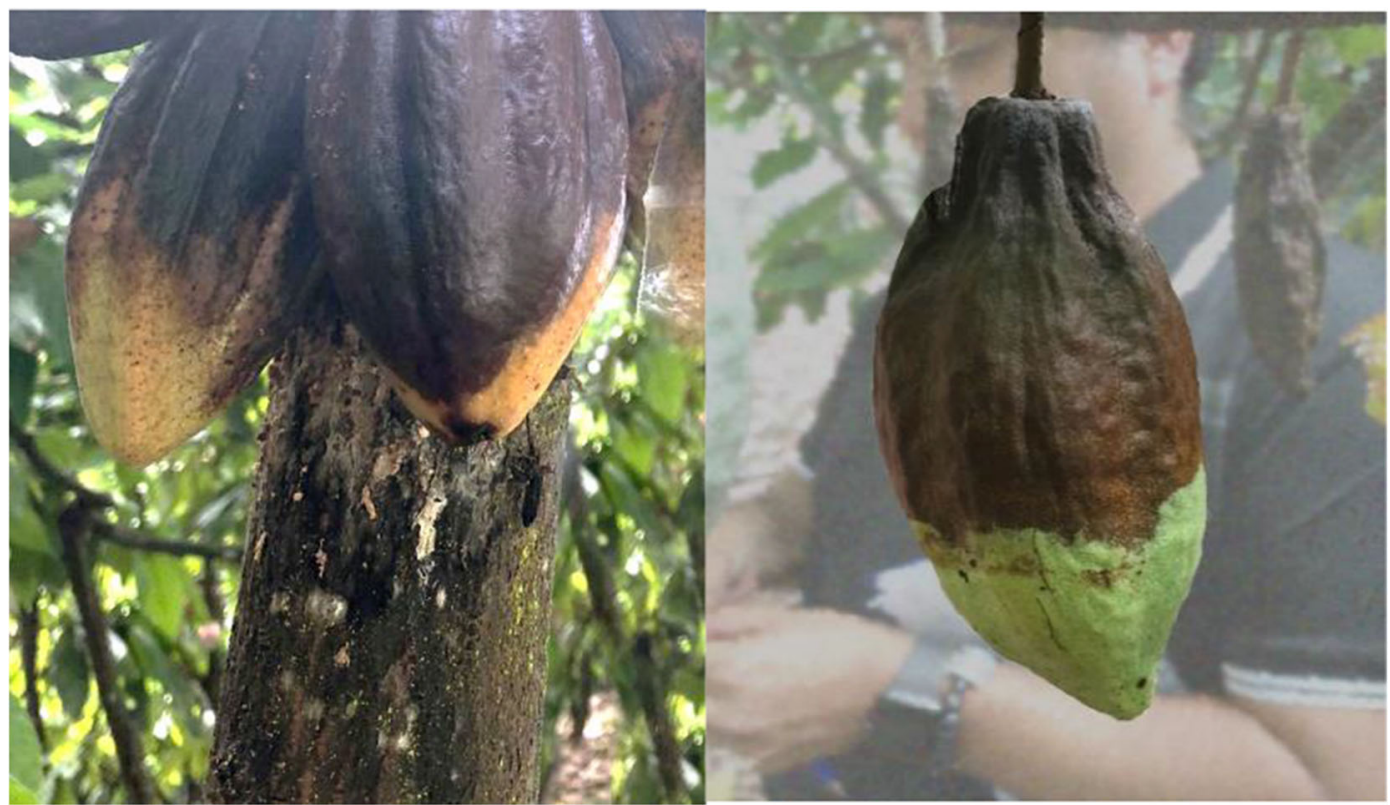

Fig. 1 Symptoms caused by N. parvum on mature and immature T. cacao pods in the field in Hawaii. Lesion margins range from even to irregular and color is variable

imager (Amersham Biosciences) and ImageQuant TL software (GE Healthcare).

The BigDye Terminator v 3.1 Cycle sequencing Kit (Perkinelmer inc., Branchburg, NJ) was used for sequencing reactions, following the manufacturer's protocols, on an ABI PRISM 3730xl genetic analyzer using Pop 7 polymer (Applied Biosystems, Foster City, CA). Forward and reverse sequences were aligned, and edited using Geneious 8.1 (biomatters Ltd., Auckland, New Zealand) and analyzed in BLASTn for identification. All sequences generated in this study were deposited in GenBank.

\section{Phylogenetic comparison}

To investigate relationships between Neofusicoccum and Lasiodiplodia isolates causing disease on T. cacao, ITS, $\beta$-tubulin, and TEF $1-\alpha$ sequences were used to build a phylogenetic tree in MEGA $X$ (Kumar et al. 2018), with sequences aligned using MUSCLE algorithm (Edgar 2004). Prior to tree construction, the best nucleotide substitution models were determined for each gene with the MEGA X models function. Models were selected according to the Akaike Information Criterion (AIC). The evolution models were JC for ITS, JTT for TEF1- $\alpha$, and
T92 for $\beta$-tubulin. Initial tree(s) for the heuristic search were obtained automatically by applying.

Neighbor-Join and BioNJ algorithms to a matrix of pairwise distances estimated using the Maximum Composite Likelihood (MCL) approach, and then selecting the topology with superior log likelihood value. Codon positions included were $1 \mathrm{st}+2 \mathrm{nd}+$ $3 \mathrm{rd}+$ Noncoding. All positions with less than $95 \%$ site coverage were eliminated, i.e., fewer than 5\% alignment gaps, missing data, and ambiguous bases were allowed at any position (partial deletion option).

Trees were drawn to scale, with branch lengths measured in the number of substitutions per site.

Sequences of Lasiodiplodia theobromae (M400, PR1) included in the phylogenetic analysis are from isolates obtained from diseased stems and pods of T. cacao. M400 was obtained from a cacao stem experiencing severe dieback in Miami and PR1 from a pod from Puerto Rico with necrotic lesions. ITS, TEF1- $\alpha$, and $\beta$-tubulin sequences from four additional representatives of each species were retrieved from GenBank (Table 1). Sequences of an isolate of $N$. batangarum found causing pod rot on cacao in Miami was also included (previously unpublished). 
Table 1 Isolates of Neofusicoccum spp. and Lasiodiplodia theobromae used in the phylogenetic analyses in this study. Sequence numbers in italics were obtained from the GenBank public database

\begin{tabular}{|c|c|c|c|c|c|c|}
\hline Isolate & Species & Host & Origin & ITS & TEF $1-\alpha$ & $\beta$-tub \\
\hline $\mathrm{H} 20$ & Neofusicoccum parvum & Theobroma cacao & Hawaii & MN435155 & MN536697 & MN536686 \\
\hline $\mathrm{H} 23$ & N. parvum & T. cacao & Hawaii & MH449672 & MN536698 & MN536687 \\
\hline $\mathrm{H} 24$ & N. parvum & T. cacao & Hawaii & MN435156 & MN536699 & MN536688 \\
\hline $\mathrm{H} 40$ & N. parvum & T. cacao & Hawaii & MN442121 & MN536700 & MN536689 \\
\hline $\mathrm{H} 44$ & N. parvum & T. cacao & Hawaii & MN442119 & MN536701 & MN536690 \\
\hline $\mathrm{H} 45$ & N. parvum & T. cacao & Hawaii & MN445613 & MN536702 & MN536691 \\
\hline isolate $\mathrm{A}$ & N. parvum & T. cacao & Hawaii & $M G 650104$ & $M G 649080$ & MG649077 \\
\hline MTZ08 & N. parvum & Syzygium cordatum & South Africa & KY052949 & KY024627 & KY000129 \\
\hline LW43-2 & N. parvum & $\mathrm{n} / \mathrm{a}$ & China & $M G 836707$ & $M G 879022$ & $M G 879024$ \\
\hline YZU181091 & N. parvum & Prunus persica & China & МH800291 & МH800293 & MH800292 \\
\hline Eqx & N. batangarum & T. cacao & Florida & MH449671 & MN536696 & MN536685 \\
\hline CMW28315 & N. batangarum & Terminalia catappa & Cameroon & FJ900606 & FJ900652 & FJ900633 \\
\hline 253 & N. batangarum & Nephelium lappaceum & Puerto Rico & MK282731 & $M K 294149$ & MK294082 \\
\hline CMM0943 & N. batangarum & Vitis vinifera & Brazil & $M G 956819$ & $M G 979494$ & $M G 979553$ \\
\hline FIFD & N. batangarum & Opuntia ficus-indica & Sicily & MF414730 & MF414768 & MF414749 \\
\hline XKD-1 & N. kwambonambiense & Fragaria ananassa & China & $M K 217323$ & $M K 246813$ & $M K 246814$ \\
\hline MAN28 & N. kwambonambiense & Syzgium cordatum & South Africa & KY052923 & KY024606 & KY000109 \\
\hline CBS1027 & N. kwambonambiense & Carya illinoensis & USA & $K X 464169$ & $K X 464686$ & KX464964 \\
\hline CAA755 & N. kwambonambiense & Eucalyptus globulus & Portugal & KT440946 & KT441006 & KX505917 \\
\hline CMW13992 & N. cordaticola & Syzgium cordatum & South Africa & EU821898 & EU821868 & EU821838 \\
\hline DUR27 & N. cordaticola & Syzgium cordatum & South Africa & KY052984 & KY024653 & KY000156 \\
\hline EL33 & N. cordaticola & Syzgium cordatum & South Africa & KY053029 & KY024681 & KY000195 \\
\hline MAR17 & N. cordaticola & Syzgium cordatum & South Africa & KY052991 & KY024660 & KY000163 \\
\hline MAN40 & N. umdonicola & Syzgium cordatum & South Africa & KY052929 & KY024611 & KY000114 \\
\hline RB11 & N. umdonicola & Syzgium cordatum & South Africa & KY052967 & KY024638 & KY000141 \\
\hline MAR11 & N. umdonicola & Syzgium cordatum & South Africa & KY052989 & KY024658 & KY000161 \\
\hline EL19 & N. umdonicola & Syzgium cordatum & South Africa & KY053023 & KY024677 & KY000190 \\
\hline CMW7772 & N. ribis & Ribes spp. & New York & AY236935 & $A Y 236877$ & AY236906 \\
\hline SEAL2 & N. ribis & Vaccinium virgatum & USA & JN607097 & $J N 607120$ & JN607120 \\
\hline SEGA5 & N. ribis & Vaccinium virgatum & USA & JN607098 & JN607121 & $J N 607145$ \\
\hline SENC29 & N. ribis & Vaccinium virgatum & USA & JN607100 & $J N 607123$ & $J N 607147$ \\
\hline M400 & Lasiodiplodia theobromae & T. cacao & Florida & MN446021 & MN536705 & MN536694 \\
\hline PR1 & L. theobromae & T. cacao & Puerto Rico & MN446742 & MN536706 & MN536695 \\
\hline PD161 & L. theobromae & Pistacia vera & USA & GU251122 & $G U 251254$ & $G U 251782$ \\
\hline xf06 & L. theobromae & Torreya grandis & China & $M G 367177$ & $M G 367172$ & $M G 367182$ \\
\hline GX-5-5A & L. theobromae & Vitis vinifera & China & $J X 275780$ & $J X 462288$ & $J X 462262$ \\
\hline ZWLT481 & L. theobromae & Cocos nucifera & China & MK051003 & MK051099 & MK051097 \\
\hline
\end{tabular}

Temperature growth response

The influence of temperature on growth of six $N$. parvum isolates obtained in this study was determined at a range of temperatures $\left(10{ }^{\circ} \mathrm{C}\right.$ to $35^{\circ} \mathrm{C}$ in $5^{\circ}$ intervals). The isolates of L. theobromae, M400 and PR1, were included for reference. Agar plugs $(6 \mathrm{~mm})$ from 2-day-old cultures growing at $27 \pm 2{ }^{\circ} \mathrm{C}$ on $2 \%$ MEA Petri dishes $\left(85 \times 15 \mathrm{~mm}^{2}\right)$ were placed top side down in the center of new $2 \%$ MEA plates, with 
four to six replicates per isolate. The plates were wrapped with parafilm and placed in the dark at the selected temperature for 3 days after which the radius $(\mathrm{cm})$ of resulting colonies was measured twice for each plate at right angles to each other, then subtracting the radius of the original agar plug $(3 \mathrm{~mm})$. Radii were averaged to produce a single measurement per plate, and the experiment was conducted twice.

Differences in temperature growth response among isolates was assessed by conducting an analysis of variance (ANOVA) on radial growth at each temperature. Data were pooled for statistical analyses due to the low variability. Data from $35^{\circ} \mathrm{C}$ were log-transformed prior to analysis, and due to variability, experiments were analyzed as an incomplete random block design using PROC MIXED in SAS Ver. 9.4 (SAS Institute 2016). Radial growth at $10^{\circ} \mathrm{C}$ and $40^{\circ} \mathrm{C}$ was analyzed using a welch ANOVA (Proc Glimmix) to account for unequal variance of the data. Means were separated using Tukey-Kramer Comparison lines for least squares means of the isolates.

\section{Pathogenicity}

Wounded pod inoculation. The virulence of the six isolates of $N$. parvum in relation to well-established pathogens $P$. palmivora (isolated from $T$. cacao in Hawaii) and L. theobromae (isolate PR1, from a diseased pod in Puerto Rico) was assessed by comparing lesion size 4 days after inoculating the wounded surfaces of immature pods. Fruit surfaces were wounded with 1mm-diameter probe at a depth of $2 \mathrm{~mm}$, and $6 \mathrm{~mm}$ discs of $1 / 2$ PDA with actively growing mycelia of each isolate were placed mycelial-side down over the site, covered with a damp $1 \times 1 \mathrm{~cm}^{2}$ filter paper square, and wrapped in parafilm. Four to six replications were done per isolate, and pods were then placed in sealed plastic bags incubated in a growth chamber at $25{ }^{\circ} \mathrm{C}$. Lesion diameter was measured after 4 days. The experiment was repeated on three different clones: GNV 164, GNV 360, and ICS 95. Mycelial discs of uncolonized 1/2 PDA were used as the negative control.

Unwounded pod inoculations. To determine the ability of the six isolates of $N$. parvum, and isolates of L. theobromae, $P$. palmivora to infect unwounded pods, inoculation studies were carried out with four to fivemonth-old pods of GNV 164, GNV 360, ICS 95, SHRS 21, and SHRS 33. Inoculations were done as described above, but without wounding pod epidermis. After
4 days, presence or absence of a lesion was recorded. $1 / 2$ PDA was used as a negative control. To confirm the lesion was caused by the inoculated isolate, a subset of lesions was processed as described above and the identity of the re-isolated organism was confirmed based on morphology. Data were pooled for descriptive statistics. The experiment was repeated on five different clones: GNV 164, GNV 360, ICS 95, SHRS 21, and SHRS 33. Due to low availability of ICS 95 pods, this genotype was not inoculated with $L$. theobromae. For each cacao clone, three to six replicates were done for each isolate, depending on pod availability.

Wounded stem inoculations. To compare the virulence of N. parvum, Lasiodiplodia theobromae, and Phytophthora palmivora, inoculations were done on 10-month-old Amelonado seedlings ranging from 50 to $120 \mathrm{~cm}$ in height and $1-1.5 \mathrm{~cm}$ in diameter. Trees were wounded with a $6 \mathrm{~mm}$ diameter cork borer $(4 \mathrm{~mm}$ depth) and the excised tissue was replaced with $6 \mathrm{~mm}$ mycelial disks from 2 to 4-day old cultures of $N$. parvum (the six isolates from Hawaii), L. theobromae (M400, isolated from a diseased stem in Miami), P. palmivora (isolated from T. cacao in Hawaii), or $1 / 2$ PDA (negative control). Inoculation sites were covered with a damp filter paper square, secured with parafilm, and kept in Percival Growth Chambers within the USDA-ARS Plant Pathology laboratory $\left(25^{\circ} \mathrm{C} ; 12 \mathrm{~h}\right.$ light/dark). Five weeks after inoculation, the bark was removed and vertical lesion length in the xylem was measured. The experiment was arranged in an unbalanced block design, with four replications per isolate. Two to three isolates (inoculation points) were included in each of the 15 blocks (trees). A subset of lesions was processed as described above and the identity of the re-isolated organism was confirmed based on morphology. Statistical analysis. To determine whether disease severity on stem differed among isolates, analysis of variance (ANOVA) was conducted on vertical lesion length, using PROC MIXED in SAS Ver. 9.4 (SAS Institute 2016). Means were separated using Tukey-Kramer Comparison lines for least squares means of the isolates.

Unwounded stem inoculations. To determine the ability of the six isolates of $N$. parvum, and isolates of L. theobromae, and P. palmivora to infect unwounded plants, inoculations were done as described above, but without wounding the bark. The experiment was arranged in an unbalanced block design with eight separate blocks, each containing three to four isolates (inoculation points). Each isolate was replicated eight times 
$(n=8)$. To confirm the lesion was caused by the inoculated isolate, a subset of lesions was processed as described above and the identity of the re-isolated organism was confirmed based on morphology. Data were pooled for descriptive statistics, but due to low infection frequency, they were not analyzed statistically.

\section{Results}

Pathogen identification

All six isolates of Neofusicoccum recovered from symptomatic pods on Oahu and Hawaii Island yielded a fastgrowing fungus with white, aerial mycelia that turned dark gray within 4 days (Puig et al. 2019), which were identified as Neofusicoccum parvum following BLASTN analysis of ITS (99\% match to MF631021), TEF1 $\alpha$ (100\% match to FJ150710), and $\beta$-tub (100\% match to KX464975) sequences. All matching sequences were generated from organisms isolated in Hawaii from a range of host plants such as Metrosideros polymorpha, Pipturus albidus, and T. cacao. Searches were limited to sequences deposited between 2012 and 2019 to account for recent additions and changes within the genus. The Neofusicoccum isolate causing pod rot in Miami, FL was identified as $N$. batangarum based on $100 \%$ identity. All ITS, TEF $1 \alpha$, and $\beta$-tub sequences obtained in this study were deposited in GenBank.

\section{Phylogenetic comparison}

Evolutionary relationships among Neofusicoccum and Lasiodiplodia isolates causing disease on T. cacao were inferred in MEGA X using the Maximum Likelihood method for Internal transcribed spacer, elongation factor, and $\beta$-tub sequences. ITS tree was constructed using the Jukes-Cantor model (Jukes and Cantor 1969) and the final dataset contained 37 nucleotide sequences and 417 positions. The tree with the highest log likelihood $(-821.29)$ is shown in Fig. 4a.

Phylogenetic relationships among elongation factor sequences were inferred using JTT matrix-based model (Jones et al. 1992) using a discrete Gamma distribution ( 5 categories $(+\mathrm{G}$, parameter $=0.3361)$ ). This analysis involved 37 amino acid sequences, translated assuming a standard genetic code table, and 62 total positions in the final dataset. The tree with the highest log likelihood $(-1017.64)$ is shown in Fig. 4b.
For $\beta$-tub sequences, a phylogenetic tree was constructed using the Tamura 3-parameter model (Tamura 1992). This analysis involved 37 nucleotide sequences and had 400 positions in the final dataset. The tree with the highest log likelihood (-787.56) is shown in Fig. 4c. All N. parvum isolates from Hawaii, except H44, consistently clustered with other $N$. parvum isolates. Isolate H44 did not cluster consistently with any species. It grouped with $N$. ribis in one tree (Fig. 4A), $N$. cordaticola in another (Fig. 4B), and alone in the third (Fig. 4C).

Temperature growth effect

Temperature responses of six $N$. parvum and two L. theobromae isolates were assessed to determine growth rate and ideal conditions. Maximum growth of all isolates was measured at $30^{\circ} \mathrm{C}$, with maximum mean radii of $6.65 \pm 0.26 \mathrm{~cm}$ for $N$. parvum $(\mathrm{H} 24)$ and $9.97 \pm$ $0.33 \mathrm{~cm}$ for L. theobromae (M400) (Fig. 2) Radial growth of $L$.

theobromae isolates after 3 days was significantly greater than $N$. parvum at all temperatures except $10^{\circ} \mathrm{C}$ and $15^{\circ} \mathrm{C}$ (ESM 1). Neofusicoccum parvum had negligible growth at $10^{\circ} \mathrm{C}(<5 \mathrm{~mm})$ and no growth at $40{ }^{\circ} \mathrm{C}$, while $L$. theobromae had no growth at $10^{\circ} \mathrm{C}$ and negligible growth at $40{ }^{\circ} \mathrm{C}(<5 \mathrm{~mm})$. Isolates of $N$. parvum from Oahu (H20, H23, H24) had greater growth than isolates from Hawaii island ( $\mathrm{H} 40, \mathrm{H} 44$, $\mathrm{H} 45$ ) at $10{ }^{\circ} \mathrm{C}, 20{ }^{\circ} \mathrm{C}, 25{ }^{\circ} \mathrm{C}$, and $30^{\circ} \mathrm{C}$. Growth did not differ between $L$. theobromae isolates at any temperature tested.

Pathogenicity

Inoculations were carried out on wounded pods of GNV 164, GNV 360, and ICS 95 to determine differences in virulence of $N$. parvum isolates relative to L. theobromae and P. palmivora on cacao (Table 2). No statistically significant differences were found among isolates on clones, with $p$-values ranging from $p<0.063$ for GNV164, to $p<0.91$ for GNV 360. Lesion sizes on GNV 360 pods were the least variable, ranging from 2.48 to $3.60 \mathrm{~cm}$ mean diameter (Table 2). In addition, all species induced lesions of similar appearance, with firm texture, and dark, even margins (Fig. 3). Pathogen species could not be distinguished based on symptomatology. None of the negative controls developed lesions. 


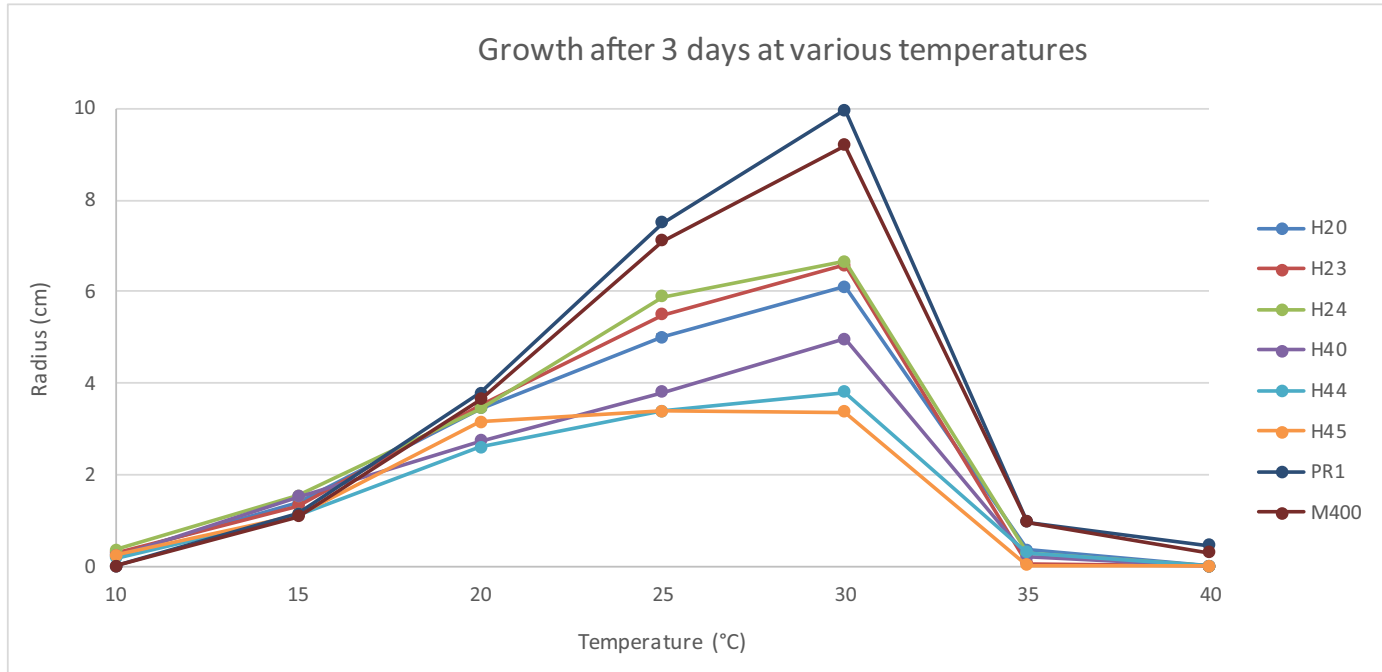

Fig. 2 Growth curves of Lasiodiplodia theobromae (M400 and PR1) and Neofusicoccum parvum (H20, H23, H24, H40, H44, and H45) based on mean radius $(\mathrm{cm})$ at temperatures from $10{ }^{\circ} \mathrm{C}$ to $40{ }^{\circ} \mathrm{C}$

Unwounded inoculations were carried out to determine the ability of isolates to infect pods in the absence of wounds. $N$. parvum and L. theobromae showed infection in $80-100 \%$ on unwounded GNV 164 pods, $40-75 \%$ on GNV 360 (Table 3). Also, N. parvum showed infection of $0-66.7 \%$ on ICS 95 . Lesions developed at all sites inoculated with P. palmivora. Pods from clones SHRS 21 and SHRS 33 did not develop lesions following inoculation with $N$. parvum. However, SHRS 21 developed lesions at $20 \%$ of $L$. theobromae inoculation points and $75 \%$ of $P$. palmivora. A single inoculation point of P. palmivora produced a lesion on SHRS 33.
Inoculations were done on wounded and unwounded stems of Amelonado seedlings to asses pathogenicity on stem tissue. On wounded stems, lesion sizes differed among isolates $(p<0.009)$, with $P$. palmivora producing larger lesions $(5.53 \mathrm{~cm})$ than all isolates except $\mathrm{H} 23(2.75 \mathrm{~cm})$. On unwounded stems, P. palmivora was also the most pathogenic, inducing lesions at 50\% of the inoculation points. Isolate $\mathrm{H} 45$ of $N$. parvum induced a lesion at only one of the eight inoculation points $(12.5 \%)$. No lesions developed following inoculation with the other isolates (Table 4).

Table 2 Mean lesion diameter (cm) on wounded pods of Theobroma cacao inoculated with isolates of Neofusicoccum parvum, Lasiodiplodia theobromae, and Phytophthora palmivora. Average diameter of pod lesions was calculated 4 days after inoculation

\begin{tabular}{lllr}
\hline Isolate & GNV 164 pod \pm S.D. $(n=4)$ & GNV 360 pod \pm S.D. $(n=4)$ & ICS 95 pod \pm S.D. $(n=3-6)$ \\
\hline H20 (N. parvum) & $5.18( \pm 1.10)$ & $3.14( \pm 0.51)$ & $3.10( \pm 0.33)$ \\
H23 (N. parvum) & $6.59( \pm 1.03)$ & $2.84( \pm 0.19)$ & $2.70( \pm 0.52)$ \\
H24 (N. parvum) & $4.57( \pm 0.60)$ & $3.18( \pm 0.29)$ & $2.68( \pm 1.10)$ \\
H40 (N. parvum) & $3.69( \pm 1.14)$ & $3.31( \pm 2.17)$ & $1.93( \pm 0.13)$ \\
H44 (N. parvum) & $5.11( \pm 0.81)$ & $2.64( \pm 1.29)$ & $1.90( \pm 0.71)$ \\
H45 (N. parvum) & $3.99( \pm 3.35)$ & $2.48( \pm 0.49)$ & $2.14( \pm 0.36)$ \\
PR1 (L. theobromae) & $7.60( \pm 2.97)$ & $3.54( \pm 0.62)$ & $n / a$ \\
H33 (P. palmivora) & $6.06( \pm 1.64)$ & $3.60( \pm 0.62)$ & $4.37( \pm 0.67)$ \\
\hline
\end{tabular}

S.D. = standard deviation of the mean

$\mathrm{n}=$ the number of inoculation points for each isolate in each experiment 


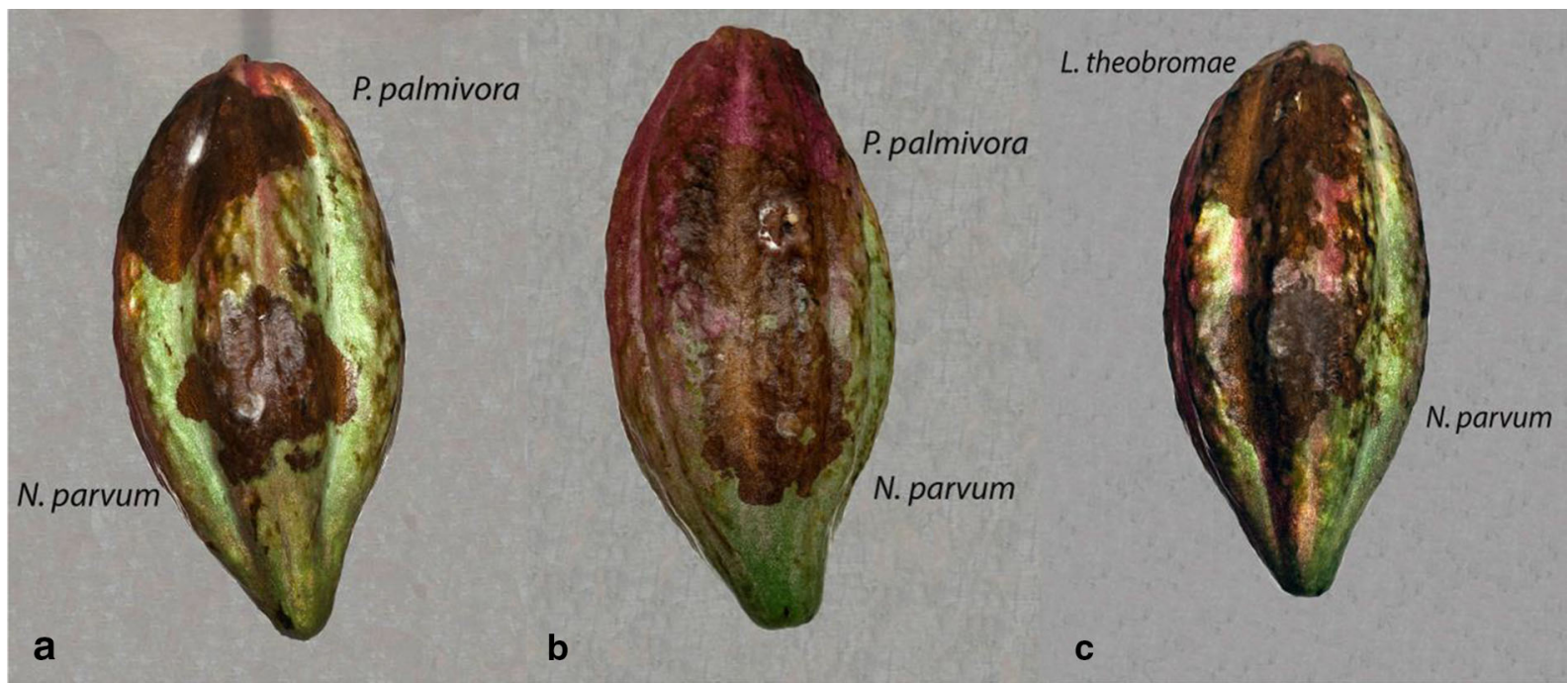

Fig. 3 Symptoms caused by $P$. palmivora, L. theobromae, and $N$. parvum on unwounded T. cacao pods. Immature pods of clone GNV 164 were inoculated with mycelial discs and lesions were measured 4 days later. Lesions ranged from reddish to dark brown and margins ranged from irregular to even

\section{Discussion}

Neofusicoccum parvum was recently found to be the cause of pod rot on T. cacao (Puig et al. 2019) and here is shown to cause infection on unwounded cacao pods within a few days. Previous studies (Slippers et al. 2013) suggested that Neofusicoccum spp. fill similar environmental niches as Lasiodiplodia spp., with the latter more prevalent in tropical climates. This is supported by results of this study which show that $N$. parvum has a

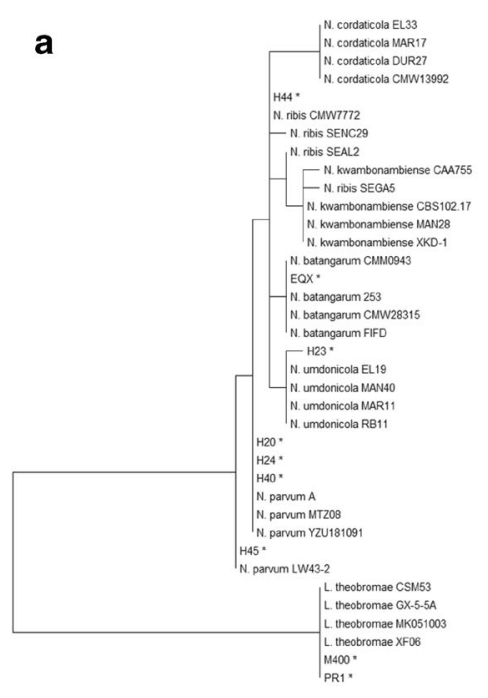

20.10

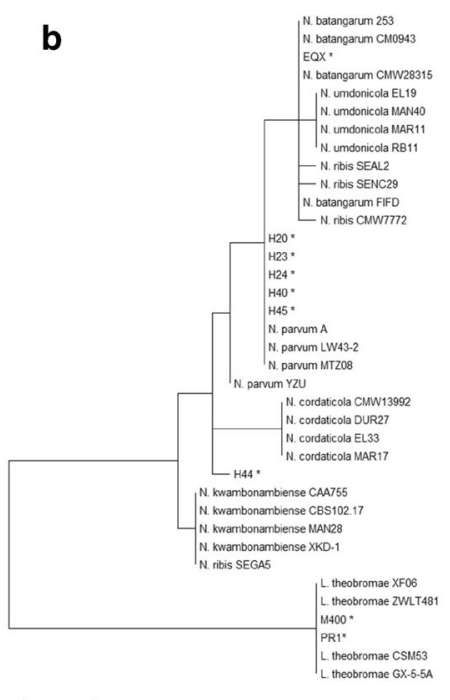

0.010

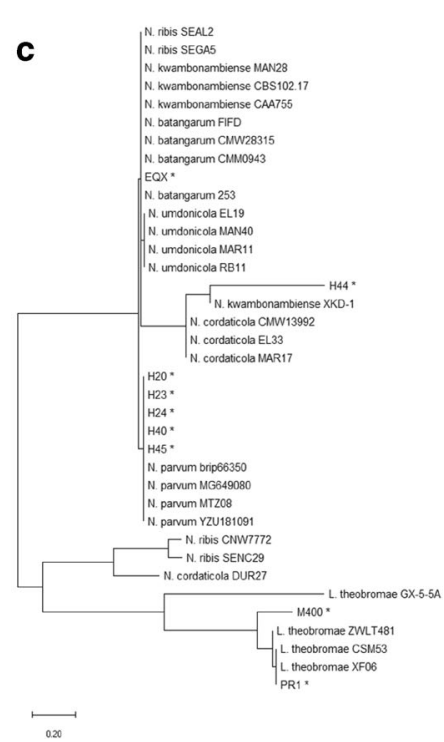
020

Fig. 4 Phylogenetic trees were created using Maximum Likelihood method in Mega X with Internal transcribed spacer (a), Beta-tubulin (b), and elongation factor (c) sequences. All sequences obtained in this study are followed with an asterisk 
Table 3 Percentage infection on unwounded pods of Theobroma cacao with isolates of Neofusicoccum parvum, Lasiodiplodia theobromae, and Phytophthora palmivora. Successful infection was measured as number of lesions that developed in relation to number of inoculation points (IP). Pod infection was assessed 4 days after inoculation

\begin{tabular}{|c|c|c|c|c|c|}
\hline Isolate & $\begin{array}{l}\% \text { infection } \\
\text { GNV } 164 \text { (n) }\end{array}$ & $\begin{array}{l}\% \text { infection } \\
\text { GNV } 360 \text { (n) }\end{array}$ & $\begin{array}{l}\% \text { infection } \\
\text { ICS } 95 \text { (n) }\end{array}$ & $\begin{array}{l}\% \text { infection } \\
\text { SHRS } 21(n)\end{array}$ & $\begin{array}{l}\% \text { infection } \\
\text { SHRS 33(n) }\end{array}$ \\
\hline H20 (N. parvum) & $80 \%(5)$ & $40 \%(5)$ & $25 \%(4)$ & $0 \%(4)$ & $0 \%(5)$ \\
\hline $\mathrm{H} 23$ (N. parvum) & $100 \%(5)$ & $75 \%(4)$ & $66.7 \%(3)$ & $0 \%(5)$ & $0 \%(5)$ \\
\hline H24 (N. parvum) & $100 \%(4)$ & $40 \%(5)$ & $33.3 \%(3)$ & $0 \%(5)$ & $0 \%(5)$ \\
\hline H40 (N. parvum) & $83 \%(6)$ & $50 \%(4)$ & $25 \%(4)$ & $0 \%(5)$ & $0 \%(5)$ \\
\hline H44 (N. parvum) & $100 \%(6)$ & $40 \%(5)$ & $0 \%(3)$ & $0 \%(5)$ & $0 \%(5)$ \\
\hline H45 (N. parvum) & $100 \%(4)$ & $75 \%(4)$ & $66.7 \%(3)$ & $0 \%(5)$ & $0 \%(5)$ \\
\hline PR1 (L. theobromae) & $100 \%(5)$ & $60 \%(5)$ & $\mathrm{n} / \mathrm{a}$ & $20 \%(5)$ & $0 \%(4)$ \\
\hline H33 (P. palmivora) & $100 \%(5)$ & $100 \%(4)$ & $\mathrm{n} / \mathrm{a}$ & $75 \%(4)$ & $20 \%(4)$ \\
\hline
\end{tabular}

$\mathrm{n}=$ the number of replicates (inoculation points) for each isolate in each experiment

lower temperature optimum and range, than L. theobromae, which continued growing at $40^{\circ} \mathrm{C}$, the highest temperature tested.

All N. parvum isolates obtained during this study (except H44) grouped together based on analyses of the ITS, TEF1- $\alpha$, and $\beta$-tub gene sequences. Despite this, significant differences in temperature response were observed between isolates from Oahu (H40, H44, $\mathrm{H} 45)$ and those from Hawaii Island (H20, H23, H24),

Table 4 Lesion development on wounded and unwounded stems of Amelonado seedlings inoculated with isolates of Neofusicoccum parvum, Lasiodiplodia theobromae, and Phytophthora palmivora. Lesion development was calculated five weeks after inoculation as vertical length $(\mathrm{cm})$ for wounded stems, and yes/no for unwounded stems

\begin{tabular}{|c|c|c|}
\hline Isolate & $\begin{array}{l}\text { Mean lesion length } \\
(\mathrm{cm}) \pm \text { S.D. }(n=4)\end{array}$ & $\begin{array}{l}\text { Percent lesion } \\
\text { development } \\
\text { on unwounded } \\
\text { stems }(n=8)\end{array}$ \\
\hline H33 (P. palmivora) & $5.53( \pm 1.27) \mathrm{A}$ & $50 \%$ \\
\hline H23 (N. parvum) & $2.75( \pm 1.14) \mathrm{AB}$ & $0 \%$ \\
\hline M400 (L. theobromae) & $1.78( \pm 0.28) \mathrm{B}$ & $0 \%$ \\
\hline H24 (N. parvum) & $1.65( \pm 0.90) \mathrm{B}$ & $0 \%$ \\
\hline H45 (N. parvum) & $1.55( \pm 0.79) \mathrm{B}$ & $12.5 \%$ \\
\hline H44 (N. parvum) & $1.33( \pm 0.50) \mathrm{B}$ & $0 \%$ \\
\hline H40 (N. parvum) & $1.10( \pm 0.59) \mathrm{B}$ & $0 \%$ \\
\hline H20 (N. parvum) & $1.00( \pm 0.32) \mathrm{B}$ & $0 \%$ \\
\hline
\end{tabular}

S.D. = standard deviation of the mean

$\mathrm{n}=$ the number of inoculation points for each isolate in each experiment

means followed by different letters are significant at $\alpha=0.05$ with the latter group showing significantly greater growth at most temperatures tested. Maximum growth of all isolates and species was recorded at $30{ }^{\circ} \mathrm{C}$, mean radii of $L$. theobromae up to three-fold greater than those of $N$. parvum. Given adequate nutrient availability, mycelia of this species could grow over $3 \mathrm{~cm}$ per day. Despite this, no differences in virulence were detected between L. theobromae and N. parvum.

High proportions of lesion development (up to 80\%) on unwounded cacao pods following inoculation with $N$. parvum indicates that the pathogen does not need wounds to infect cacao pods. Stomatal frequency on pods may be responsible for the variation in infection in unwounded pods observed among the five clones used in this study, as was previously suggested for P. palmivora (Iwaro et al. 1997). Although $P$. palmivora occasionally produces appressoria to penetrate pod epidermis, most infection occurs through stomata on the pod surface (Ali et al. 2016).

Infection of $P$. palmivora has been shown to spread from fruit to stem and vice versa through the peduncle (Firman 1974). In the field, necrotic lesions on pods from which $N$. parvum was isolated, were radiating from the peduncle. These trees may have also had pathogen infection in the woody tissue without detectable symptoms having developed. In grapevines, it takes months, up to years, for detectable symptoms to develop following initial colonization by $N$. parvum (Bertsch et al. 2013). It would be beneficial to determine how long it takes for stem infections in $T$. cacao to become externally visible. 
$\mathrm{H} 23$ and $\mathrm{H} 45$ were the N. parvum isolates with the greatest infectivity on unwounded pods, $100 \%, 75 \%$, and $66.7 \%$ on GNV 164, GNV 360, and ICS 95, respectively. In addition, one tree developed a stem lesion following inoculation with $\mathrm{H} 45$, despite the absence of wounds. These results indicate that $N$. parvum is a pathogen of similar virulence as $L$. theobromae, which was recognized as the cause of pod rot on $T$. cacao pods in 1895 (Mbenoun et al. 2007), dieback in 1908 (Dudgeon 1910), and causes substantial losses in Cameroon and India (Mbenoun et al. 2008; Kannan et al. 2010). Although described as a wound pathogen (Akrofi et al. 2016), results from this study show that mycelia of $L$. theobromae can infect healthy, unwounded cacao pods. In addition to producing lesions of similar size, $N$. parvum, L. theobromae, and P. palmivora induce lesions of similar appearance, with firm texture, and dark, even margins. Pathogen species could not be distinguished based on symptomatology.

This study is the first study to show that $P$. palmivora infects unwounded stems. Although literature on canker of $T$. cacao, mentions wounding as the entryway for these pathogens, the $50 \%$ infection in unwounded stems observed here, suggests that infected pods in contact with stems or branches can be important reservoirs in the disease cycle of Phytophthora canker. N. parvum infected a single unwounded stem, but it is not clear if there was a natural opening such as leaf scar, which allowed the pathogen to enter. However, all inoculations performed in this study used mycelial discs, which may not be the infective propagules present in nature. Espinoza et al. (2009) reported lesions two to three times larger on blueberry stems inoculated with conidial suspensions compared to those inoculated with mycelia. In addition, viable spores of $N$. parvum are present yearround in California avocado orchards and vineyards, peaking soon after rain events (Eskalen et al. 2013; Urbez-Torres et al. 2010). More research is needed to identify the role of conidia in the infection cycle.

Pruning, or other wounds, are likely the main source of entry into the stems but fruits easily become infected without wounds, increasing the likelihood of the pathogen spreading to contacting fruit. In areas with high incidence of $N$. parvum, removal of infected fruits and chemical treatment of pruning wounds may be an effective way to prevent infections. Although $N$. parvum is highly sensitive to fludioxonil and iprodione (Latorre et al. 2013), the impact of this pathogen on production must be quantified to determine the economic threshold for fungicide application.

\section{Conclusion}

All Neofusicoccum isolates obtained from diseased cacao pods in Hawaii were confirmed to be N. parvum, a species recently reported as a pathogen on cacao for the first time. $N$. parvum can infect unwounded pods, with infection incidences near $100 \%$, on some clones. However, more research is needed to determine whether this species can infect unwounded stems. This is also the first report of $L$. theobromae infecting healthy, unwounded cacao pods. The ability to directly penetrate plant tissue has a significant impact on disease management, as minimizing wounding will have less of an effect on disease incidence. It is necessary to determine conditions favoring pathogen growth and survival and how the pathogen spreads from one tree to the next.

Supplementary Information The online version contains supplementary material available at https://doi.org/10.1007/s10658021-02210-1.

Acknowledgements We would like to thank Susan Schenck, Chifumi Nagai, and Tyler Jones from Hawaii Agriculture Research Center, Kunia, HI for assisting with the sampling on Oahu, and Jonathan Albo for his role in the molecular characterization and pathogenicity screening.

Compliance with ethical standards The authors declare that the present manuscript complies with the ethical standards outlined by the European Journal of Plant Pathology.

Conflict of interest The authors declare no conflict of interest.

Open Access This article is licensed under a Creative Commons Attribution 4.0 International License, which permits use, sharing, adaptation, distribution and reproduction in any medium or format, as long as you give appropriate credit to the original author(s) and the source, provide a link to the Creative Commons licence, and indicate if changes were made. The images or other third party material in this article are included in the article's Creative Commons licence, unless indicated otherwise in a credit line to the material. If material is not included in the article's Creative Commons licence and your intended use is not permitted by statutory 
regulation or exceeds the permitted use, you will need to obtain permission directly from the copyright holder. To view a copy of this licence, visit http://creativecommons.org/licenses/by/4.0/.

\section{References}

Akrofi, A. Y., Amoako-Atta, I., Acheampong, K., Assuah, M. K., \& Melnick, R. L. (2016). Fruit and canopy pathogens of unknown potential risk. In B. A. Bailey \& L. W. Meinhardt (Eds.), Cacao diseases: A history of old enemies and new encounters (pp. 361-382). Cham: Springer International Publishing.

Ali, S. S., Amoako-Attah, I., Bailey, R. A., Strem, M. D., Schmidt, M., Akrofi, A. Y., Surujdeo-Maharaj, S., Kolawole, O. O., Begoude, B. A. D., ten Hoopen, G. M., Goss, E., PhillipsMora, W., Meinhardt, L. W., \& Bailey, B. A. (2016). PCRbased identification of cacao black pod causal agents and identification of biological factors possibly contributing to Phytophthora megakarya's field dominance in West Africa. Plant Pathology, 65(7), 1095-1108. https://doi.org/10.1111 /ppa.12496.

Bertsch, C., Ramírez Suero, M., Magnin Robert, M., Larignon, P., Chong, J., Abou Mansour, E., Spagnolo, A., Clément, C., \& Fontaine, F. (2013). Grapevine trunk diseases: Complex and still poorly understood. Plant Pathology, 62(2), 243-265.

Bittenbender, H. C. (2005). History of Hawaii cacao. Paper presented at the Hawaii cacao symposium. Hawaii: Kona.

Bittenbender, H. C. (2016). Hawaii Cacao Survey. In Department of Tropical Plant and Soil Sciences. CTAHR: University of Hawaii at Mānoa.

Carbone, I., \& Kohn, L. M. (1999). A method for designing primer sets for speciation studies in filamentous ascomycetes. Mycologia, 91(3), 553-556. https://doi.org/10.1080 /00275514.1999.12061051.

Chee, K., \& Foong, K. (1968). Use of cacao pod for recovering Phytophthora species pathogenic to Hevea brasiliensis. Plant Disease Report, 52(1), 5.

Chen, X., He, B., Li, H.-X., Cernava, T., Sang, W., Yang, M.-F., et al. (2019). First report of black rot on walnut fruits caused by Neofusicoccum parvum in China. Plant Disease, 103, 3275. https://doi.org/10.1094/pdis-02-19-0387-pdn.

Dudgeon, G. C. (1910). Notes on two west African Hemiptera injurious to cocoa. Bulletin of Entomological Research, 1(1), 59-61. https://doi.org/10.1017/S0007485300000079.

Edgar, R. C. (2004). MUSCLE: Multiple sequence alignment with high accuracy and high throughput. Nucleic Acids Research, 32(5), 1792-1797. https://doi.org/10.1093/nar/gkh340.

Eskalen, A., Faber, B., \& Bianchi, M. (2013). Spore trapping and pathogenicity of fungi in the Botryosphaeriaceae and Diaporthaceae associated with avocado branch canker in California. Plant Disease, 97(3), 329-332.

Espinoza, J. G., Briceño, E. X., Chávez, E. R., Úrbez-Torres, J. R., \& Latorre, B. A. (2009). Neofusicoccum spp. associated with stem canker and dieback of blueberry in Chile. Plant Disease, 93(11), 1187-1194.

Firman, I.D. (1974). Cocoa canker. In Phytophthora Disease of Cocoa (ed. P.H. Gregory), pp. 131-140. Longman, London.
Glass, N. L., \& Donaldson, G. C. (1995). Development of primer sets designed for use with the PCR to amplify conserved genes from filamentous ascomycetes. Applied and Environmental Microbiology, 61(4), 13231330.

Hughes, M. A., Heller, W. P., Friday, J. B., Weaver, W., \& Keith, L. M. (2018). First report of Neofusicoccum parvum causing stem necrosis of 'Ōhi'a Trees (Metrosideros polymorpha) on O‘ahu, Hawai' i, U.S.A. Plant Disease, 102(12), 2660-2660. https://doi.org/10.1094/pdis-06-18-1002-pdn.

Hui-Fang, N. I., Hong-Ren, Y., Ruey-Shyang, C., Ruey-Fen, L., \& Ting-Hsuan, H. (2012). New Botryosphaeriaceae fruit rot of mango in Taiwan: Identification and pathogenicity. Botanical Studies, 53(4), 467-478.

Ismail, A. M., Cirvilleri, G., Lombard, L., Crous, P. W., Groenewald, J. Z., \& Polizzi, G. (2013). Characterisation of Neofusicoccum species causing mango dieback in Italy. Journal of Plant Pathology, 95(3), 549-557.

Iturritxa, E., Slippers, B., Mesanza, N., \& Wingfield, M. J. (2011). First report of Neofusicoccum parvum causing canker and die-back of eucalyptus in Spain. Australasian Plant Disease Notes, 6(1), 57-59. https://doi.org/10.1007/s13314-0110019-5.

Iwaro, A. D., Sreenivasan, T. N., \& Umaharan, P. (1997). Phytophthora resistance in cacao ( Theobroma cacao ): Influence of pod morphological characteristics. Plant Pathology, 46, 557-565.

Jones, D. T., Taylor, W. R., \& Thornton, J. M. (1992). The rapid generation of mutation data matrices from protein sequences. Computer Applications in the Biosciences, 8, 275-282.

Jukes, T. H., \& Cantor, C. R. (1969). Evolution of protein molecules. In H. N. Munro (Ed.), Mammalian Protein Metabolism (pp. 21-132). New York: Academic Press.

Kannan, C., Karthik, M., \& Priya, K. (2010). Lasiodiplodia theobromaecauses a damaging dieback of cocoa in India. Plant Pathology, 59(2), 410-410. https://doi.org/10.1111 j.1365-3059.2009.02192.x.

Kumar, S., Stecher, G., Li, M., Knyaz, C., \& Tamura, K. (2018). MEGA X: Molecular evolutionary genetics analysis across computing platforms. Molecular Biology and Evolution, 35(6), 1547-1549. https://doi.org/10.1093/molbev/msy096.

Latorre, B. A., Torres, R., Silva, T., \& Elfar, K. (2013). Evaluation of the use of wound-protectant fungicides and biological control agents against stem canker (Neofusicoccum parvum) of blueberry. Ciencia e Investigación Agraria, 40(3), 537545.

Luque, J., Elena, G., Garcia-Figueres, F., Reyes, J., Barrios, G., \& Legorburu, F. J. (2014). Natural infections of pruning wounds by fungal trunk pathogens in mature grapevines in Catalonia (Northeast Spain). Australian Journal of Grape and Wine Research, 20(1), 134-143. https://doi. org/10.1111/ajgw.12046.

Mbenoun, M., Momo Zeutsa, E. H., Samuels, G., Nsouga Amougou, F., \& Nyasse, S. (2007). Dieback due to Lasiodiplodia theobromae, a new constraint to cocoa production in Cameroon. New Disease Reports, 15, 59.

Mbenoun, M., Momo Zeutsa, E. H., Samuels, G., Nsouga Amougou, F., \& Nyasse, S. (2008). Dieback due to Lasiodiplodia theobromae, a new constraint to cocoa production in Cameroon. Plant Pathology, 57(2), 381-381. https://doi.org/10.1111/j.1365-3059.2007.01755.x. 
Molina-Gayosso, E., Silva-Rojas, H. V., García-Morales, S., \& Avila-Quezada, G. (2012). First report of black spots on avocado fruit caused by Neofusicoccum parvum in Mexico. Plant Disease, 96(2), 287-287. https://doi.org/10.1094/pdis08-11-0699.

Oliveira, M. S., Wang, N.-Y., Marin, M. V., \& Peres, N. A. (2019). First report of Lasiodiplodia theobromae and Neofusicoccum parvum/N. ribis species complex causing fruit rot on strawberry in the United States. Plant Disease, 103(5), 1037-1037. https://doi.org/10.1094/pdis-09-181531-pdn.

Puig, A. S., Marelli, J. P., Matsumoto, T. K., Keith, L. M., \& Gutierrez, O. A. (2019). First report of Neofusicoccum parvum causing pod rot on cacao in Hawaii. Plant Disease, 103(6), 1416-1416. https://doi.org/10.1094/pdis-10-181719pdn.

Rusin, C., Di Francesco, A., Di Foggia, M., D'Aquino, S., Rombolà, A., Tugnoli, V., et al. (2019). An emerging problem affecting apple production: Neofusicoccum parvum. Aureobasidium pullulans L1 and L8 strains as an alternative control strategy. Biological Control, 134, 157-162. https://doi.org/10.1016/j.biocontrol.2019.04.015.

SAS Institute. (2016). SAS software version 9.4. Cary: SAS Institute.

Slippers, B., Boissin, E., Phillips, A. J., Groenewald, J. Z., Lombard, L., Wingfield, M. J., et al. (2013). Phylogenetic lineages in the Botryosphaeriales: A systematic and evolutionary framework. Studies in Mycology, 76(1), 31-49. https://doi.org/10.3114/sim0020.
Tamura, K. (1992). Estimation of the number of nucleotide substitutions when there are strong transitiontransversion and $\mathrm{G}+$ C-content biases. Molecular Biology and Evolution, 9(4), 678-687.

Úrbez-Torres, J. R., \& Gubler, W. D. (2009). Pathogenicity of Botryosphaeriaceae species isolated from grapevine cankers in California. Plant Disease, 93(6), 584-592. https://doi. org/10.1094/pdis-93-6-0584.

Urbez-Torres, J. R., Battany, M., Bettiga, L. J., Gispert, C., McGourty, G., Roncoroni, J., Smith, R. J., Verdegaal, P., \& Gubler, W. D. (2010). Botryosphaeriaceae species sporetrapping studies in California vineyards. Plant Disease, 94, $717-724$.

USDA (2016). Hawaii tropical fruits and crops report 2016. https://www.nass.usda.gov/Statistics_by_ State/Hawaii/Publications/Sugarcane_and_Specialty_ Crops/Sugarcane/2017/201709tropicalspecialtiesHI.pdf. Accessed Aug 2019.

White, T. J., Burns, T., Lee, S., \& Taylor, J. (1990). Amplification and direct sequencing of fungal ribosomal RNA genes for phylogenetics. In M. Innis, D. H. Gelfand, J. J. Snisky, \& T. J. White (Eds.), PCR protocols a guide to methods and applications (pp. 315-332). San Diego: Academic Press.

Zea-Bonilla, T., González-Sánchez, M. A., Martín-Sánchez, P. M., \& Pérez-Jiménez, R. M. (2007). Avocado dieback caused by Neofusicoccum parvum in the Andalucia region, Spain. Plant Disease, 91(8), 10521052. https://doi.org/10.1094 /pdis-91-8-1052b. 